\title{
STUDI KITAB SUNAN ABI DAUD
}

\author{
Fakhrurrozi \\ Program Studi Pendidikan Bahasa Arab STAI As-Sunnah Deli Serdang \\ J1. Medan-Tg. Morawa, Km. 13 G. Darmo, Desa Bangun Sari, Kecamatan Tanjung Morawa, Kab. \\ Deli Serdang. \\ ro.zi24@yahoo.co.id
}

\begin{abstract}
Abstrak Salah satu kitab Sunan Arba'ah ialah kitab Sunan Abi Daud. Kitab ini merupakan salah satu kitab yang menghimpun koleksi hadis Nabi saw. Penulisnya terkenal sebagai sosok ulama yang terpercaya karena integritas kepribadian dan kapasitas intelektualnya. Isi kitab ini penting dikaji, difahami untuk kemudian dijadikan sebagai pedoman hidup. Penelitian menunjukkan bahwa hadis-hadis dalam kitab ini umumnya berkualitas hasan dan merupakan hasil sortiran dari 500.000 menjadi 4.800 hadis saja, melalui penyeleksian yang sangat ketat. Kitab ini disusun dalam rentang waktu yang longgar. Meskipun sudah rampung di usia Abu Daud yang kedua puluhan, tetapi penambahan dan pengurangan terus dilakukan. Kitab ini memuat hadis-hadis hukum, yang disusun dengan sistematika fikih. Kitab ini juga banyak menyita perhatian umat Islam: ada yang mensyarah, meringkas dan bahkan menjadi pusat kajian para peneliti. Sebagaimana kitab lain, kitab Sunan juga memiliki nilai positif negatifnya. Di antara ulama yang mengkritik kitab Sunan adalah Imam Ibn al-jauzi, dengan alasan menurutnya kitab tersebut memuat beberapa hadis maudu'. Namun kritikan tersebut telah disanggah oleh Jalaluddin as-Suyuti.
\end{abstract}

Kata kunci: Sunan Abu Daud, Hadis.

\section{Pendahuluan}

Bagi umat Islam, eksistensi kitab hadis sangatlah penting. Alasan pokoknya adalah karena kedudukan isi kitab itu sendiri. Kitab-kitab hadis, merupakan sumber rujukan ajaran agama Islam setelah Alquran.

Dari sekian koleksi kitab hadis, kitab Sunan Abi Daud merupakan salah satu kitab tersebut, bahkan Sunan Abi Daud merupakan salah satu kitab induk hadis yang enam. Ini menunjukkan salah satu keistimewaan kitab ini, oleh karenanya penting terkhusus bagi umat Islam untuk mengenal lebih jauh tentang kedudukan dan isi kitab tersebut.

Aspek-aspek yang perlu dikaji tentang kitab ini selain tentang biografi penulis, adalah berkaitan dengan kuantitas dan kualitas hadis, sistematika penyusunan, penilaian para ulama tentang Abu Daud secara umum dan tentang kitab Sunan-nya secara khusus, serta hal-hal lain yang dipandang perlu guna menambah pemahaman terhadap kitab ini. 


\section{Pembahasan}

\section{Biografi Abu Daud}

\section{a. Riwayat Hidup}

Nama lengkapnya Sulaiman ibn al-Asy`asy ibn Ishaq ibn Basyir ibn Syaddad ibn 'Amar ibn 'Amir al-Azdi. Kuniyahnya adalah Abu Daud sedangkan nisbahnya adalah as-Sijistiani, sebagaimana keterangan Ibn Abi Hatim. Menurut muridnya Abu 'Ubaid al-Ajuri, beliau lahir di kota Sijistian pada tahun $202 \mathrm{H}^{1}$ dan meninggal di Basrah pada tahun $275 \mathrm{H}^{2}$

Abu Daud tumbuh di tengah keluarga yang agamis. Sejak kecil beliau mempelajari Alquran dan literatur Arab serta materi lainnya sebelum mempelajari hadis. Pada usia kurang lebih 20 tahun, beliau berkelana ke Bagdad pada tahun $221 \mathrm{H}$. Setelah dewasa beliau melakukan rihlah dengan lebih intensif untuk mempelajari hadis. Beliau melakukan perjalanan ke Hijaz, Syam, Mesir, Irak, Jazirah Arab, Khurasan, Naisabur dan Basrah. Pengembaraannya ini menunjang beliau untuk mendapatkan hadis sebanyak-banyaknya untuk dijadikan referensi dalam penyusunan kitab as-Sunan .

Pola hidup sederhana tercermin dalam kehidupannya. Hal ini terlihat dari cara berpakaiannya, yaitu salah satu lengan bajunya lebar dan satunya lagi sempit. Menurut beliau, lengan yang lebar untuk membawa kitab, sedang yang satunya tidak diperlukan, baginya lebar berarti pemborosan. Maka banyak ulama semasanya atau sesudahnya memberinya gelar zahid dan warak. ${ }^{3}$

Abu Daud berhasil meraih reputasi tinggi di kampung halamannya, Basrah. Semua penduduk Basrah kenal akan kemuliaannya. Merekapun berbondong-bondong belajar hadis kepada beliau. Sebelum Abu Daud kembali dari pengembaraannya mencari ilmu, Basrah mengalami kegersangan ilmu. Kegersangan ini disebabkan minimnya agamawan dan intelektual yang hidup di sana, karena mereka menyingkir dari Basrah setelah penyerbuan kaum Zenji pada tahun $257 \mathrm{H}^{4}$

\footnotetext{
1 'Abdullah ibn Salih al-Barrak, al-Imam Abu Daud as-Sijistiyani wa Kitabuhu as-Sunan, (Riyad: al-Furqan, 1414 H), h.7-8.

${ }^{2}$ Ibid., h. 34.

${ }^{3}$ Tim Penulis Tafsir Hadis Fakultas Ushuluddin IAIN Sunan Kalijaga Yogyakarta, Studi Kitab Hadis, (Yogyakarta: Teras, 2009), h. 86-87.

${ }^{4}$ Zulmani, Mengenal Kitab-Kitab Hadis, (Yogyakarta: Insan Madani, 2008), h. 104.
} 
Salah satu kisah yang menunjukkan keberanian beliau dalam hal kebenaran, meskipun terhadap pejabat ialah kisah Gubernur Basrah yang pada waktu itu mengunjungi Abu Daud di Bagdad dalam rangka meminta Abu Daud pindah ke Basrah. Dikisahkan dari Abu Bakar bin Jabir, pembantu Abu Daud, beliau berkata: "Sang Gubernur Abu Ahmad minta untuk bertemu Abu Daud. Abu Daud mengizinkan masuk. Lalu beliau dipersilahkan duduk dan Abu Daud pun bertanya, "Apa yang mendorong sang gubernur berkunjung ke sini pada jam seperti ini?"

Sang Gubernur menjawab, "Untuk tiga kepentingan."

“Kepentingan apa?” tanya Abu Daud.

Amir mengatakan, "Saya minta anda tinggal di Basrah, supaya para pelajar di seluruh dunia belajar kepadamu. Dengan demikian kota Basrah akan makmur lagi. Karena Basrah telah hancur dan ditinggalkan orang akibat tragedi Zenji.”

"Itu yang pertama. Lalu apa yang kedua?"

"Hendaknya anda mengajarkan Sunan kepada anak-anakku."

"Yang ketiga?"

"Hendaknya anda membuat majelis khusus untuk keluarga khalifah, sebab mereka enggan duduk bersama masyarakat umum."

"Permintaan ketiga ini tidak dapat kukabulkan, karena di mata ilmu, manusia sama, baik pejabat maupun masyarakat biasa. ${ }^{5}$

Atas permintaan Abu Ahmad tersebut, Abu Daud pindah ke Basrah. Di sana beliau ditunjuk sebagai pengajar hadis. Setiap hari masyarakat berduyunduyun mendatangi majelisnya. Beliau mengabdikan diri untuk mencerdaskan umat Islam. ${ }^{6}$

\section{b. Guru-gurunya}

Abu Daud bertemu dengan banyak ulama di masanya, menimba ilmu dari mereka bahkan sempat berguru dengan guru-gurunya Imam Bukhari dan Muslim, seperti Ahmad ibn Hanbal, Ishaq ibn Rahawaih, Ibn Syaibah dan lain-lain.

Al-Barrak dalam bukunya yang berjudul al-Imam Abu Daud as-Sijistiyani wa Kitabuhu as-Sunan mengelompokkan guru Abu Daud kepada tiga tingkatan:

\footnotetext{
${ }^{5}$ Tim Penulis, Studi Kitab Hadis,h. 87. Lihat juga, Al-Barrak, al-Imam Abu Daud ... h.9.

${ }^{6}$ Al-Barrak, al-Imam Abu Daud ... h.9.
} 
pertama, guru-guru seniornya. Kedua, guru-gurunya yang paling banyak meriwayatkan hadis dari mereka. Ketiga, guru-gurunya yang sejawat. Untuk lebih rinci berikut akan diuraikan berdasarkan tingkatan masing-masing: ${ }^{7}$

\begin{tabular}{|c|l|c|l|c|l|c|}
\hline No & Tingkat Satu & Wafat & Tingkat Dua & Wafat & Tingkat Tiga & $\begin{array}{c}\text { Wafa } \\
\mathrm{t}\end{array}$ \\
\hline 1 & Abu 'Amar ad-Darir & 220 & $\begin{array}{l}\text { Musaddad Ibn } \\
\text { Masrahid }\end{array}$ & 228 & $\begin{array}{l}\text { 'Umar as- } \\
\text { Sijistiyani }\end{array}$ & 264 \\
\hline 2 & 'Asim ibn Ali & 221 & Ibn Ma`in & 233 & Al-Abbas & 269 \\
\hline 3 & Ibrahim ar-Razi Ibn & 220 & Ali al-Madini & 234 & Al-Hasan & 260 \\
\hline 4 & $\begin{array}{l}\text { Abdullah } \\
\text { Maslamah }\end{array}$ & $\begin{array}{l}\text { Ishaq Ibn } \\
\text { Rahawaih }\end{array}$ & $\begin{array}{l}\text { 'Abbas ad- } \\
\text { Dauri }\end{array}$ & 271 \\
\hline 5 & Muslim Ibn Ibrahim & 220 & $\begin{array}{l}\text { Qutaibah Ibn } \\
\text { Sa`id }\end{array}$ & 240 & $\begin{array}{l}\text { M. ibn 'Auf } \\
\text { at-Ta'i }\end{array}$ & 272 \\
\hline 6 & Sa`id ibn Mansur & 227 & $\begin{array}{l}\text { Ahmad Ibn } \\
\text { Hanbal }\end{array}$ & 241 & & \\
\hline 7 & & & Hannad & 241 & & \\
\hline 8 & & & M. Ibn al-`Ala & 247 & & \\
\hline 9 & & & Ibn Abi Syaibah & 235 & & \\
\hline 10 & & $\begin{array}{l}\text { M. Ibn Yahya az- } \\
\text { Zuhali }\end{array}$ & 258 & & \\
\hline 11 & & & M. Ibn Basysyar & 252 & & \\
\hline
\end{tabular}

Ibn Hajar dalam kitab Tahzib at-Tahzib menjelaskan, guru-guru Imam Abu Daud tercatat sejumlah 300 orang, namun al-Barrak hanya memuat 241 nama saja. ${ }^{8}$

\section{c. Murid-muridnya}

Kepakaran Imam Abu Daud dalam bidang Hadis membuatnya dikerumuni para penuntut ilmu dari berbagai penjuru. Bahkan teman-teman sebayanya pun tidak mau ketinggalan menghadiri majelisnya. Berikut adalah sebagian muridmurid beliau yang terpopuler:

\begin{tabular}{|c|l|c|c|l|c|}
\hline No & Nama Murid & W & No & Nama Murid & W \\
\hline 1 & Imam an-Nasa'i & 303 & 16 & Al-Hasan asy-Syasyi & \\
\hline 2 & Ibrahim Ibn Hamdan & & 17 & Al-Hasan Ibn 'Abdullah & \\
\hline 3 & Ahmad Ibn Ibrahim al-Asynani & & 18 & Al-Husain Ibn Idris & \\
\hline 4 & Abu Hamid Ahmad al-Asbahani & & 19 & Zakaria Ibn Yahya & 307 \\
\hline 5 & Abu Bakar Ahmad an-Najjad & 348 & 20 & Anak Abu Daud Abu Bakar & 316 \\
\hline 6 & Abu Amar Ahmad Ibn Ali & & 21 & Ibn Abi ad-Dunya & 381 \\
\hline 7 & Ahmad Ibn Muhammad Sulaim & & 22 & Ali Ibn al-Hasan al-Ansari & 328 \\
\hline 8 & Abu Sa`id Ahmad al-A`rabi & 340 & 23 & Abu Bisyr Mhd. ad-Dulabi & 320 \\
\hline 9 & Ahmad al-Khallal al-Hafiz & 311 & 24 & Ahmad Ibn 'Amar al-Lu'lui & 333 \\
\hline 10 & Ahmad Yasin & & 25 & Muhammad Ibn Dasah & 346 \\
\hline 11 & Ahmad Ibn al-Mu`alla & & 26 & Abu 'Uwanah al-Isfirayini & 316 \\
\hline 12 & Ishaq Ibn Musa ar-Ramli & & 27 & Imam at-Tirmizi & 279 \\
\hline 13 & Isma'il as-Saffar & & 28 & Abu 'Ubaid Ibn Ali al-Ajuri & \\
\hline 14 & Harb al-Karmani & & 28 & Abdurrahman ar-Ramhurmuzi & \\
\hline 15 & Muhammad Ibn Abdul Malik & & 30 & Abu al-Hasan Mhd. al-Firyabi & \\
\hline
\end{tabular}

${ }^{7}$ Ibid., h. 14-16.

${ }^{8}$ Ibid. h. 14-25. 


\section{d. Karya-karyanya}

Imam Abu Daud terkenal sebagai sosok ulama yang tekun dalam menuntut ilmu, mengumpulkannya dari para ulama, kemudian menyusunnya dalam bentuk tulisan. Karya-karyanya dapat dikategorikan kepada tiga kategori, yaitu: 1) karyakaryanya dalam bentuk buku yang sudah dicetak, 2) dalam bentuk makhtutat, manuskrip. 3) karya-karyanya yang hilang dari peredaran alias tidak ditemukan sampai sekarang. Berikut akan diuraikan karya-karya beliau menurut tiga kategori di atas $^{9}$ :

\section{1) Dalam Bentuk Buku}

a) Sunan Abu Daud.

Kitab Sunan Abu Daud telah ditecak berulang-kali, antara lain ialah:

- Cetakan India, oleh Dahli, tahun 1171 H.

- Cetakan India, satu jilid, tahun $1260 \mathrm{H}$.

- Cetakan India, tahun 1290 H.

- Cetakan Mesir, oleh al-Matba`ah al-Kastiliyah, tahun $1280 \mathrm{H}$.

- Cetakan India, oleh Haidar Abad, 1321 H.

- Dicetak dalam dua jilid, berikut syarah Abu al-Hasanat al-Finjani, tahun $1318 \mathrm{H}$.

- Cetakan Mesir, dua jilid, ta`liq Ahmad Sa`ad, tahun $1371 \mathrm{H}$.

- Cetakan India, Tab`ah Hijriyah, 4 jilid, tahun 1322 H. Di antara cetakan yang ada, cetakan ini dianggap cetakan paling akurat karena telah disesuaikan dengan sebelas nuskhah dari riwayat al-Lu'lu'i, dan satu nuskhah dari riwayat Ibn Dasah. Kemudian dicetak kembali di Madinah pada tahun $1388 \mathrm{H}$. Cetakan ini terdiri dari empat belas jilid.

- Cetakan Muhammad Muhyiddin 'Abdul Hamid, cetakan pertama pada tahun $1354 \mathrm{H}$, cetakan kedua tahun $1369 \mathrm{H}$.

b) Al-Marasil. Buku ini pada asalnya merupakan bagian dari kitab Sunan beliau, tetapi ulama menjadikannya dalam satu kitab tersendiri, karena isinya memang kumpulan hadis-hadis mursal. ${ }^{10}$ Kitab ini dicetak pertama

${ }^{9}$ Ibid., h. 35-39.

${ }^{10}$ Hadis mursal sebagaimana telah dimaklumi, adalah hadis di mana ujung sanadnya terputus. Yang dimaksud ujung sanad di sini ialah perawi sebelum Nabi saw, yakni sahabat atau tabiin. Keterputusan tersebut bisa jadi hanya satu orang atau lebih. Hadis mursal hukumnya daif, 
kalinya pada tahun $1310 \mathrm{H}$ di Mesir namun pada cetakan ini sanadnya dibuang. Kemudian kitab tersebut kembali dicetak lengkap dengan sanadnya oleh Dar ar-Risalah, pada tahun $1408 \mathrm{H}$.

c) Masa'il Abi Daud li al-Imam Ahmad. Kitab ini merupakan kumpulan pertanyaan tentang fikih yang pernah diajukan oleh Abu Daud kepada Imam Ahmad. Kitab ini dicetak pada tahun $1353 \mathrm{H}$, yang ditahkik oleh sekh Muhammad Rasyid Rido.

d) Risalah Abi Daud li Ahli Makkah. Risalah ini berupa penjelasan Imam Abu Daud kepada warga kota Mekah tentang kitab Sunan-nya. Kitab ini juga telah dicetak berulang kali. Cetakan terakhir ditahkik oleh sekh Muhammad as-Sabbag di Beirut pada tahun $1394 \mathrm{H}$.

e) Ar-Ruwat min al-Ikhwah wa al-Akhwat. Kitab ini ditahkik oleh Basim alJawabirah, kemudian dicetak oleh Dar ar-Rayah pada tahun $1408 \mathrm{H}$.

f) Su'alat Abi 'Ubaid al-Ajuri Aba Daud fi al-Jarh wa at-Ta'dil. Juz 3, 4 dan 5. Cetakan juz 3 diterbitkan al-Jami`ah al-Islamiyah Madinah, pada tahun $1399 \mathrm{H}$ dengan pentahkik Muhammad Ibn Ali al-Umari.

\section{2) Dalam Bentuk Manuskrip}

a) Su'alat Abi 'Ubaid al-Ajuri Aba Daud fi al-Jarh wa at-Ta'dil, juz 3 dan 4.

b) As'ilah li al-Imam Ahmad ibn Hanbal fi ar-Ruwat as-Siqat wa adDu 'afa'.Sistematika kitab ini ada dua: pertama, Abu Daud membuat namanama kota. Di bawah nama kota tersebut dibuat nama-nama perawi yang berasal dari kota itu. Kedua, urutan nama-nama perawi di dalam kota itu pun diurutkan lagi berdasarkan kesiqahannya. Pertama Abu Daud memulainya dengan perawi yang siqah, baru kemudian perawi yang daif. Dengan kata lain, setiap kota ada perawi yang siqah ada juga perawi yang daif. Dalam penyusunan nama-nama tersebut, Abu Daud mendahulukan nama-nama perawi yang siqah dulu baru setelah itu perawi yang daif.

c) Az-Zuhd.

karena tidak bisa dipastikan apakah yang terputus itu melibatkan tabiin. Tabiin tidak semuanya siqah, bisa jadi perawi yang terputus itu ialah tabiin yang tidak siqah, sehingga itulah alasan mengapa hadis mursal dihukumi daif. 


\section{3) Kitab-kitab Beliau yang Menghilang}

a) An-Nasikh wa al-Mansukh. Oleh Ibn Khair al-Asybaili kitab tersebut diberi nama Nasikh al-Aqur'an wa Mansukhuhu.

b) Al-Qadar.

c) Al-Ba`su wa an-Nusyur.

d) Dala'il an-Nubuwwah.

e) At-Tafarrud fi ad-Din.

f) Musnad Malik ibn Anas.

g) Fada'il al-Ansar.

h) Ashab asy-Sya`bi.

i) Kitab al-Kuna.

j) Ibtida' al-Wahy.

k) Akhbar al-Khawarij.

1) Kitab ad-Du`a.

m) Al-Masa'il al-Lati Halafa 'Alaiha Ahmad. ${ }^{11}$

\section{e. Sanjungan Ulama kepada Beliau}

Seluruh ulama sepakat memberikan sanjungan positif kepada Imam Abu Daud, sebagai salah seorang ulama besar di dalam agama Islam, terkenal baik dan saleh. Berikut adalah beberapa sanjungan ulama terhadap beliau:

a. Ibn Abi Hatim: Abu Daud adalah seorang yang siqah.

b. Abu Bakar al-Khallal: Abu Daud adalah Imam,tidak seorang pun mengunggulinya dalam penguasaan takhrij.

c. Ibn Hibban: Abu Daud adalah salah seorang Imam Dunia baik dalam berbagai aspek pengetahuan: fikih, ilmu, hafalan, ibadah, kewarakan dan keteguhan ilmu pengetahuan.

d. Ibrahim al-Harbi dan Muhammad ibn Ishaq as-Sagani: Ketika Abu Daud menyusun kitab Sunan-nya, dilembutkan kepadanya Hadis sebagaimana dilembutkannya besi kepada Nabi Daud.

e. Imam al-Hakim: Abu Daud adalah Imam Ahli Hadis tanpa tandingan.

\footnotetext{
${ }^{11}$ Ibid.
} 
f. Ahmad ibn Muhammad al-Harawi: Beliau adalah salah seorang penghafal hadis Rasulullah, yang menekuni ilmu hadis, ilat hadis, sanad hadis, ahli ibadah, menjaga kehormatan dirinya, saleh, warak dan salah satu pendekar Hadis.

g. Muhammad ibn Makhlad: Abu Daud sanggup mengeluarkan 100.000 hadis dalam keadaan muzakarah.

h. Maslamah ibn Qasim: siqah, zuhud, pakar Hadis di masanya.

i. Musa ibn Harun: Saya tidak pernah melihat orang yang lebih bagus darinya.

j. Ibn al-Jauzi: alim, hafiz, pakar ilat hadis, terpelihara kehormatannya dan warak.

k. Imam az-Zahabi: Imam, Sabat, Panglima penghafal, hujjah, adil, Syaikh assunnah.

1. Ibn Hajar: siqah, hafiz, pembesar ulama. ${ }^{12}$

Dari karya-karya tersebut di atas, yang paling popular adalah kitab Sunan Abi Daud. Menurut al-Barrak, kitab tersebut selesai ditulis sebelum tahun $220 \mathrm{H}$. kitab ini dijadikan Abu Daud sebagai rujukan beliau dalam mengajarkan hadis di Bagdad, sebelum menetap di Basrah. Ketika kitab itu ditunjukkan kepada gurunya Imam Ahmad, dia mengatakan bahwa kitab tersebut sangat bagus. ${ }^{13}$

\section{Kitab Sunan Abi Daud}

\section{a. Nama Kitab}

Dalam isi suratnya ke penduduk Mekah, Imam Abu Daud menamakan kitabnya dengan nama Sunan. Dalam kesempatan lain beliau menyebutkan, hadishadis yang termuat dalam kitab Sunan rata-rata adalah hadis masyhur. Dua pernyataan Imam Abu Daud di atas terlihat secara tegas bahwa Abu Daud sendiri menamai kitabnya dengan kitab Sunan. Kitab sunan ialah kitab hadis yang disusun secara sistematis berdasarkan urutan bab fikih.

\section{b. Posisi Sunan Abu Daud di antara Sunan Lain}

Sunan Abu Daud berada diposisi ketiga setelah Sahih Bukhari dan Muslim, bahkan sebagian ulama ada yang memposisikan Sunan Abu Daud sejajar dengan Sahih Muslim.

\footnotetext{
${ }^{12}$ Al-Barrak, al-Imam Abu Daud ... h. 41.

${ }^{13}$ Tim Penulis ..., Studi Kitab Hadis, h. 91.
} 


\section{c. Penilaian Ulama terhadap kitab Sunan Abu Daud}

Di antara pandangan positif ulama terhadap Sunan Abu Dawud antara lain: ${ }^{14}$

1) Ibn Mandah: Ulama yang memilah-milah antara hadis yang sahih dengan yang tidak ialah: al-Bukhari, Muslim kemudian Abu Daud dan an-Nasa'i. Kitabnya, selain merupakan salah satu kitab yang meliputi hadis-hadis hukum, ia juga merupakan salah satu rujukan utama tentang dalil-dalil fikih, karena sistematikanya yang mengikuti pola fikih.

2) Imam an-Nawawi: Hendaknya bagi siapa pun yang bergelut di dunia fikih, merujuk kitab Sunan Abi Daud. Selain di dalamnya terdapat banyak hadishadis hukum, ia juga mudah dijangkau dan ringkas.

3) Al-Khattabi: "Ketahuilah kitab Sunan Abu Daud adalah sebuah kitab yang mulia mengenai hadis-hadis hukum yang belum pernah suatu kitab disusun sepertinya. Para ulama menerima dengan baik kitab Sunan tersebut. Karenanya, dia menjadi hakim antara ulama dan fuqaha yang berlainan mazhab. Kitab ini menjadi pegangan ulama Irak, Mesir, Maroko, dan negeri lain."

4) Ibn Qayyim al-Jauziyyah: "Kitab Sunan Abu Daud memiliki kedudukan tinggi dalam dunia Islam dan sebagai pemberi keputusan bagi perselisihan pendapat. Kepada kitab itulah orang-orang jujur mengharapkan keputusan. Mereka merasa puas atas keputusan dari kitab tersebut, karena Abu Daud telah menghimpun segala macam hadis hukum dan menyusunnya dengan sistematika yang baik dan indah, serta membuang hadis yang lemah.”

5) Ibn al-“Arabi: “Apabila seseorang sudah memiliki Kitabullah dan kitab Sunan Abu Daud, maka ia tidak lagi memerlukan kitab lainnya."

6) Abu Hamid al-Gazali: "Kitab Sunan Abu Daud sudah cukup bagi para mujtahid untuk mengetahui hadis-hadis tentang hukum."

\section{d. Sitematika Penyusunan}

Abu Daud menyusun kitabnya menurut sistematika atau urutan bab-bab fikih. Metode seperti ini dapat memudahkan pembaca untuk mencari hadis-hadis

\footnotetext{
${ }^{14}$ Dzulmani, Mengenal Kitab-Kitab Hadis, (Yogyakarta: Insan Madani, 2008), h. 111. Lihat juga: Al-Barrak, al-Imam Abu Daud ... h. 66.
} 
yang berkaitan dengan masalah tertentu. Adapun sistematika atau urutan penulisan hadis dalam kitab Sunan Abu Daud sebagai berikut: ${ }^{15}$

\begin{tabular}{|c|c|c|c|}
\hline \multirow{2}{*}{ No } & \multirow{2}{*}{ Nama Kitab } & \multicolumn{2}{|c|}{ Jumlah } \\
\hline & & $\mathrm{Bab}$ & Hadis \\
\hline 1 & Kitab at-Taharah & 143 & 390 \\
\hline 2 & Kitab as-Salat & 367 & 1165 \\
\hline 3 & Kitab az-Zakat & 47 & 145 \\
\hline 4 & Kitab al-Luqatah (barang temuan) & - & 20 \\
\hline 5 & Kitab al-Manasik (manasik haji) & 98 & 325 \\
\hline 6 & Kitab an-Nikah (pernikahan) & 50 & 129 \\
\hline 7 & Kitab at-Talaq (perceraian) & 50 & 138 \\
\hline 8 & Kitab as-Saum (puasa) & 81 & 164 \\
\hline 9 & Kitab al-Jihad & 182 & 311 \\
\hline 10 & Kitab Dahaya (binatang kurban) & 20 & 56 \\
\hline 11 & Kitab as-Said (perburuan) & 4 & 18 \\
\hline 12 & Kitab al-Wasaya (wasiat) & 17 & 23 \\
\hline 13 & Kitab al-Fara'id (kewarisan) & 17 & 43 \\
\hline 14 & $\begin{array}{l}\text { Kitab al-Kharaj wa al-Imarah } \\
\text { (pajak dan kepemimpinan) }\end{array}$ & 40 & 161 \\
\hline 15 & Kitab al-Janaiz (jenazah) & 84 & 153 \\
\hline 16 & $\begin{array}{l}\text { Kitab al-Aiman wa an-Nuzur } \\
\text { (sumpah dan nazar) }\end{array}$ & 32 & 84 \\
\hline 17 & $\begin{array}{l}\text { Kitab al-Buyu' wa al-Ijarah (jual } \\
\text { beli dan sewa-menyewa) }\end{array}$ & 92 & 245 \\
\hline 18 & Kitab al-Aqdiyah (peradilan) & 30 & 70 \\
\hline 19 & Kitab al-'Ilm (ilmu) & 13 & 28 \\
\hline 20 & Kitab as-Asyribah (minuman) & 22 & 67 \\
\hline 21 & Kitab al-At'imah (makanan) & 55 & 119 \\
\hline 22 & Kitab at-Tib (pengobatan) & 24 & 71 \\
\hline 23 & Kitab al-'Itqu (pemerdekaan budak) & 15 & 43 \\
\hline 24 & $\begin{array}{l}\text { Kitab al-Huruf wa al-Qira' (huruf } \\
\text { dan bacaan) }\end{array}$ & - & 40 \\
\hline 25 & Kitab al-Hammam (kamar mandi) & 3 & 11 \\
\hline 26 & Kitab al-Libas (busana) & 47 & 139 \\
\hline 27 & $\begin{array}{l}\text { Kitab } \\
\text { rambut) }\end{array}$ at-Tarajjul $\quad$ (menghiasi & 21 & 55 \\
\hline 28 & Kitab al-Khatam (cincin) & 8 & 26 \\
\hline 29 & Kitab al-Fitan (fitnah-fitnah) & 7 & 39 \\
\hline 30 & Kitab al-Mahdi & - & 12 \\
\hline 31 & Kitab al-Malahim (peperangan) & 18 & 60 \\
\hline 32 & Kitab al-Hudud & 40 & 143 \\
\hline 33 & Kitab ad-Diyat & 32 & 102 \\
\hline 34 & Kitab as-Sunnah & 32 & 177 \\
\hline
\end{tabular}

\footnotetext{
${ }^{15}$ Ibid., h. 94.
} 


\begin{tabular}{|l|l|c|c|}
\hline 35 & Kitab al-Adab & 108 & 502 \\
\hline
\end{tabular}

\section{e. Kuantitas dan Kualitas Hadis Sunan Abu Daud}

Tentang jumlah keseluruhan hadis dalam kitab Sunan Abi Daud, paling tidak ada dua versi, sebagai berikut: Menurut versi Ibn al-'Abd, total seluruh hadis di dalam kitab Sunan Abi Daud berjumlah enam ribu hadis termasuk yang berulang-ulang, dengan rincian empat ribu hadis dengan tanpa pengulangan dan dua ribu hadis dengan katergori pengulangan.Sedangkan menurut Ibn Dasah sebagaimana tertuang pada isi surat Imam Abu Daud sendiri, total keseluruhan hadis di dalamnya adalah sekitar empat ribu delapan ratus hadis ditambah enam ratus hadisdengan kategori mursal. Dengan demikian, menurut versi terakhir ini, total seluruh hadis di dalamnya berjumlah lima ribu empat ratus. Perbedaan total hadis tersebut tidaklah aneh, di satu sisi memang sudah biasa bahwa setiap buku ada edisi revisinya dan di sisi lain bisa jadi disebabkan perbedaan metode penghitungan, atau perbedaan sistem penomoran hadis. ${ }^{16}$

Selanjutnya tentang kualitas hadis, secara garis besar, Imam Abu Daud membagi kualitas hadis dalam kitab Sunan-nya sebagai berikut:

1) Sahih, yakni sahih lizatihi.

2) Ma yusybihuhu, yang menyerupai sahih yaitu sahih ligairihi.

3) Wa yuqaribuhu, yang mendekati sahih yakni hasan lizatihi.

4) Ma kana fihi wahnun syadid, yaitu hadis yang sangat daif.

5) Tidak dikomentari Abu Daud, yakni salih atau hasan. ${ }^{17}$ Dalam hal ini Ibn Salah mengatakan, semua hadis yang terdapat dalam kitabnya tanpa diberi komentar apa-apa, tidak diriwayatkan dalam kitab sahihain, tidak pula dikomentari oleh para ulama, berarti kualitas hadis-hadis tersebut adalah hasan menurut Abu Daud. ${ }^{18}$

\section{Kitab-kitab Tentang Sunan Abi Daud}

Sunan Abi Daud salah satu kitab yang banyak disoroti oleh para ulama, pensyarah dan para peneliti. Kitab ini banyak menyita perhatian umat, mulai dari kitab-kitab syarah, kitab-kitab ringkasan bahkan menjadi bahan kajian dan

\footnotetext{
${ }^{16}$ Al-Barrak, al-Imam Abu Daud ... h. 57.

${ }^{17}$ Tim Penulis ..., Studi Kitab Hadis, h. 95.

${ }^{18}$ Al-Barrak, al-Imam Abu Daud ... h. 59.
} 
penelitian. Berikut akan disajikan beberapa kitab yang disusun berdasarkan sistematika di atas:

a. Kitab-kitab Syarah

Terdapat tiga puluh satu kitab syarah yang mensyarah kitab Sunan Abi Daud, antara lain sebagai berikut:

1) Ma`alim as-Sunan. Karya Imam al-Khattabi, $338 \mathrm{H}$

2) Syarah Imam an-Nawawi, $676 \mathrm{H}$, Tetapi kitab ini tidak sampai selesai.

3) Syarah al-Hafiz al-Maqdisi, $765 \mathrm{H}$.

4) Zawa'id Abi Daud 'Ala as-Sahihain, Syarah al-Hafiz Ibn al-Mulaqqin, 804 $\mathrm{H}$.

5) Syarah Ahmad Ibn Husain asy-Syafi i, $844 \mathrm{H}$.

6) Mirqat as-Su`ud Ila Sunan Abi Daud, syarah Jalaluddin as-Suyuti, $855 \mathrm{H}$.

7) Fath al-Wadud 'Ala Sunan Abi Daud, Syarh Abu al-Hasan Muhammad Ibn 'Abdil Hadi as-Sindi, 1138 H.

8) 'Aun al-Wadud 'Ala Sunan Abi Daud, Syarah Syihabuddin al-Marjani, $1306 \mathrm{H}$.

9) Zubdatu al-Maqsud fi Halli Ma Qala Abu Daud, syarah Muhammad Tahir ar-Rahimi, 1411 H. Kitab ini merupakan upaya mensyarah kitab Sunan Abi Daud dari ucapan Abu Daud sendiri.

b. Kitab-kitab Ringkasan

1) Muntakhab min Sunan Abi Daud, karya al-Hafiz Muhammad 'Abdul Hadi, $744 \mathrm{H}$.

2) Tahzib as-Sunan, Ibn al-Qayyim, $751 \mathrm{H}$.

3) Ringkasan al-Hafiz 'Abdul Azim al-Munziri, $656 \mathrm{H}$.

c. Penelitian tentangKitab Sunan Abi Daud

1) Sahih Sunan Abi Daud, karya sekh Albani.

2) Al-Matrukun wa Marwiyatuhum fi Sunan Abi Daud, tesis Magister di Universitas Ummul Qura', Mekah.

3) Abu Daud wa Asaruhu fi 'Ilmi al-Hadis, Tesis Magister di Universitas Ummul Qura, Mekah.

4) Al-Marasil li al-Imam Abi Daud, Tesis di Universitas Islam Madinah alMunawwarah, Madinah. 
5) Al-Usul as-Sittah: Riwayatuha wa Nusakhuha. Tesis Magister di Universitas Malik Su`ud, Riyad.

6) Ma Sakata 'Anhu Abu Daud mimma fi Isnadihi Daifun, Tesis Magister di Universitas Islam Madinah.

7) 'Aqidah al-Imam Abi Daud, Disertasi Doktoral di Universitas Islam Madinah. ${ }^{19}$

\section{Contoh Hadis dalam Sunan Abi Daud}

Variasi Bacaan Salam setelah Tasyahud

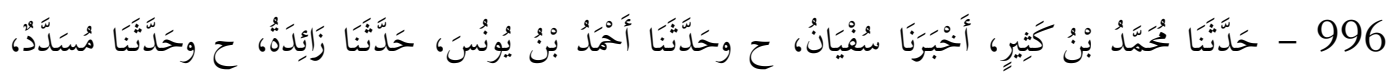

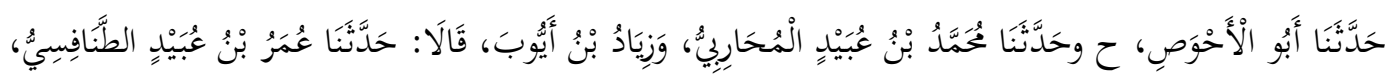

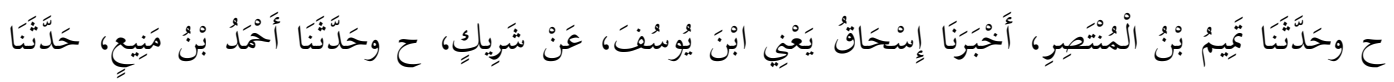

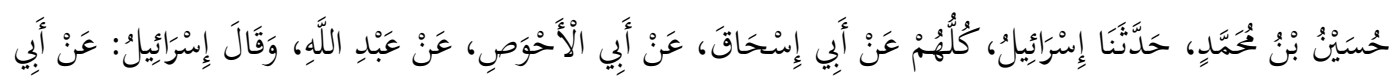

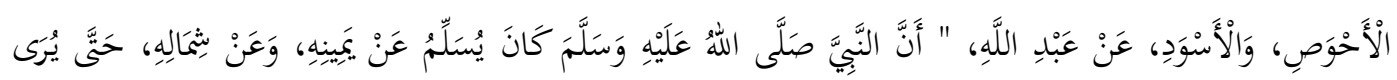

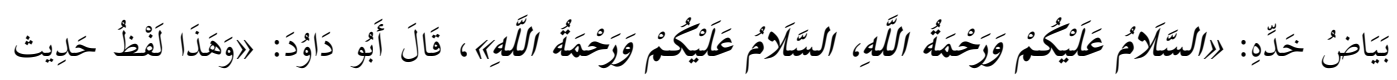

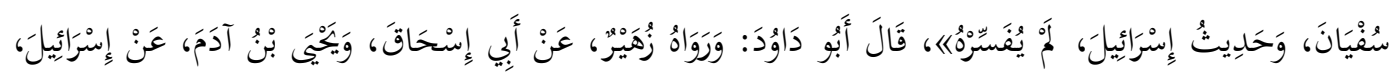

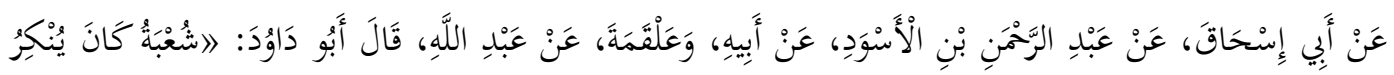
هَذَا الحَحِيثَ - حَدِيثَ أَبَي إِسنحَاقَ - أَنْ يَكُونَ مَرْفُوُعًا

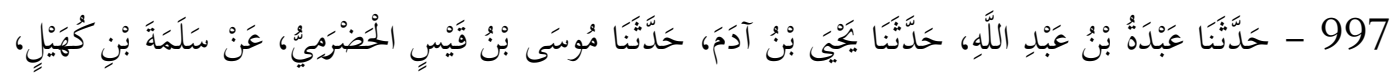

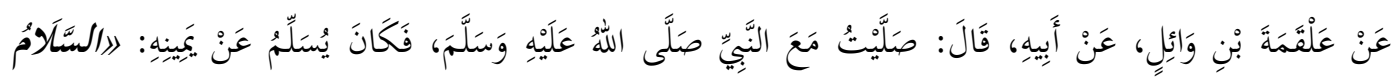

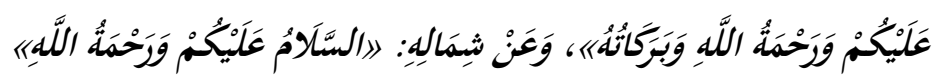

Dari Wa'il ibn Hujur beliau berkata, “Aku salat bersama Nabi saw., lalu Nabi Salam ke arah kanannya seraya mengucapkan: assalamualaikum, kemudian salam ke arah kirinya seraya mengucapkan,assalamualakum warahmatullah".

\footnotetext{
${ }^{19}$ Ibid., h. 67-80.
} 
Dua hadis di atas diletakkan oleh Imam Abu Daud pada bab salam. Persamaannya, dua hadis di atas sama-sama menggunakan lafaz assalamualaikumwarahmatullah, baik salam pertama maupun salam yang

kedua. Perbedaannya, pada hadis kedua salam pertama terdapat penambahan lafaz wabarakatuh. ${ }^{20}$ Menurut 'Abbad, tambahan lafaz wabarakatuh tersebut adalah sahih, tidak dianggap syaz. ${ }^{21}$

Dapat ditambahkan bahwa kitab Sunan Abi Daud sebagaimana dijelaskan oleh Imam an-Nawawi di muka, termasuk ringkasan tentang hadis-hadis hukum. Artinya, Imam Abu Daud hanya menyebutkan satu atau dua hadis yang cukup mewakili di bidangnya, itu pun mengutamakan hadis-hadis yang lebih berkualitas di antara yang ada. Dua hadis di atas, menjadi bukti bahwa memang benar Abu Daud sangat konsisten dengan pernyataannya yang mengatakan bahwa dirinya hanya memadakan satu atau dua hadis dalam setiap babnya. Kalaupun terkadang ditemukan lebih dari tiga atau empat hadis pada setiap babnya, itu karena dipandang masih berkaitan dan memperkaya informasi terhadap materi yang bersangkutan. $^{22}$

\section{Penutup}

Kitab Sunan Abi Daud adalah salah satu kitab koleksi hadis Nabi saw. Penulisnya sangat terkenal sebagai sosok ulama yang terpercaya karena integritas kepribadian dan kapasitas intelektualnya. Kitab ini sangat penting untuk diketahui, dikaji, difahami dan dijadikan sebagai acuan, khususnya oleh umat Islam. Studi menunjukkan bahwa hadis-hadis yang tercantum dalam kitab ini umumnya berkualitas hasan dan merupakan hasil sortiran dari 500.000 hadis hingga menjadi hanya 4.800 hadis saja, tentu melalui penyeleksian yang sangat ketat dan teliti. Kitab ini disusun dalam rentang waktu yang sangat leluasa. Meskipun Abu Daud telah menyelesaikan penulisannya di usianya yang keduapuluhan, tetapi penambahan dan pengurangan terus beliau lakukan, sehingga kitab tersebut menjadi lebih sempurna seperti yang sekarang ini. Kitab ini memuat hadis-hadis

\footnotetext{
${ }^{20}$ Abu Daud Sulaiman ibn al-Asy`as as-Sijistiyani, Sunan Abi Daud, tahkik Muhammad Muhyiddin 'Abdul Hamid, (Beirut: al-Maktabah al-'Asriyah, t.t.), jilid. I, h. 261-262.

21 'Abdul Muhsin 'Abbad, Syarh Sunan Abi Daud, (t.t.p:, t.t.), jilid. VIII, h. 125.

${ }^{22}$ Al-Barrak, al-Imam Abu Daud ... h. 61.
} 
hukum, yang disusun dengan sistematika fikih, artinya mengikuti system penyusunan bab-bab fikih. Kitab ini juga telah menyita perhatian umat Islam: ada yang mensyarah, meringkas dan bahkan menjadi pusat kajian para peneliti. Sebagaimana kitab lain, kitab Sunan juga memiliki nilai positif negatifnya. Di antara ulama yang mengkritik kitab Sunan adalah Imam Ibn al-jauzi, dengan alasan menurutnya kitab tersebut memuat beberapa hadis maudu`. Namun kritikan tersebut telah disanggah oleh Jalaluddin as-Suyuti dalam kitabnya yang berjudul al-La'ali' al-Masnu'ah fi Ahadis al-Maudu'ah, dan Ali bin Muhammad bin Iraq al-Kinani dalam kitabnya Tanzih as-Syari'ah 'an al-Akhbar asy-Syani`ah alMaudu'ah. 


\section{Pustaka Acuan}

Al-Barrak, 'Abdullah ibn Salih, al-Imam Abu Daud as-Sijistiyani wa Kitabuhu asSunan, Riyad: al-Furqan, $1414 \mathrm{H}$.

'Abbad, 'Abdul Muhsin, Syarh Sunan Abi Daud, t.t.p:, t.t.

As-Sijistiyani Abu Daud Sulaiman ibn al-Asy`as, Sunan Abi Daud, tahkik Muhammad Muhyiddin 'Abdul Hamid, Beirut: al-Maktabah al-'Asriyah, t.t.

Dzulmani, Mengenal Kitab-Kitab Hadis, Yogyakarta: Insan Madani, 2008.

Tim Penulis, Tafsir Hadis Fakultas Ushuluddin IAIN Sunan Kalijaga Yogyakarta, Studi Kitab Hadis, Yogyakarta: Teras, 2009. 